\title{
Hvordan holde på eldre, erfarne sykepleiere?
}

Det vil være et stort behov for sykepleiere i fremtiden. Derfor er det en fordel at de kan stå i jobb så lenge som mulig.

\section{Forfattere}

\section{Robert Salomon}

Forsker I

Arbeidsforskningsinstituttet/ HiOA

Hans Terjesen

Forsker

Arbeidsforskningsinstituttet/ HiOA

\section{Nøkkelord}

Eldre sykepleiere Arbeidsgiver Arbeidsmiljø Pensjon

\section{HOVEDBUDSKAP}

God helse og økonomiske forhold er viktige for å stå lenger i jobb. Eldre arbeidstakere legger vekt på redusert og mer fleksibel arbeidstid og mindre belastende arbeid. Et trygt læringsklima og arbeidsmiljø er viktig, samt at ledelsen har «blikk for alder». For å holde på eldre arbeidstakere er det viktig at seniorsamtalen blir en reell motivasjonssamtale.

Andelen eldre i befolkningen vil øke kraftig og selv om det blir en økning i antall studieplasser innen sykepleien, vil utdanningskapasiteten neppe holde tritt med behovet for sykepleiere. Ut fra beregninger av befolkningsutvikling, inklusive økning i andel eldre samt tilbudet ut fra nåværende utdanningskapasitet, har Statistisk sentralbyrå beregnet at det vil være et underskudd på 23000 årsverk sykepleiere i 2035 (1).

Skjøstad (2) har vist at det er et betydelig frafall fra sykepleieryrket tidlig i karrieren. Allerede ti år etter fullført utdanning jobber én av fem sykepleiere et annet sted enn helsetjenesten. Dette betyr at det er ekstra viktig å ta vare på sykepleiere som vil og kan fortsette å jobbe. Det er av stor samfunnsmessig betydning å sikre god tilgang på erfarne sykepleiere og beholde dem i yrket.

\section{Helse - en forutsetning}


Forekomsten av helseplager er forholdsvis stor i helse- og sosialsektoren. Det gjelder både muskel-/skjelettplager og psykosomatiske lidelser. Med tiden er det også blitt grundig dokumentert at risikoen for å pådra seg helseskader er betydelig høyere for arbeidstakere som jobber døgnkontinuerlig (3), noe svært mange sykepleiere gjør, enten i deler av eller hele sin karriere. Det er derfor særdeles viktig å sørge for å beholde og ivareta en så god arbeidshelse som mulig med tilretteleggingstiltak gjennom hele karrieren.

Helseplager og slitenhet utvikles gjennom et langt yrkesliv. Det å starte et tilretteleggingsarbeid når medarbeiderne nærmer seg pensjonsalderen har en egenverdi, men er som regel for sent for medarbeidere som føler seg utslitt eller sliter med alvorlige helseplager. Tilretteleggingsarbeidet må starte tidlig. Det skal vi komme tilbake til.

\section{$\emptyset$ konomi og pensjon}

Økonomiske forhold er viktig. Dagens pensjonssystem gir stor valgfrihet. Dersom man har opparbeidet nok pensjonspoeng ved fylte 62 år, kan man velge mellom å gå av med pensjon umiddelbart, nyte pensjonslivet fullt ut eller spare noen av pensjonspengene. Dagens pensjonssystem åpner for rett til å stå i arbeid lenger enn tidligere. I privat sektor har arbeidstakerne rett til å stå i arbeid til fylte 72 år. I offentlig sektor er grensen, med noen unntak, 70 år.

\section{«Ulempen ved å ta ut pensjon tidlig er at man spiser av 'pensjonspotten'.»}

Ulempen ved å ta ut pensjon tidlig er at man spiser av «pensjonspotten» slik at pensjonen fremover blir lavere enn om man fortsetter å jobbe. I pensjonssystemet ligger det altså en oppmuntring til å utsette pensjoneringstidspunktet. Dersom man fortsetter å jobbe, vil man også fortsette å tjene opp pensjonspoeng i folketrygden. Det er også mulig å ta ut tidligpensjon og fortsette å jobbe deltid.

Hvis man i tillegg har en offentlig tjenestepensjon, er det ikke like enkelt. Noen kan tape noe i total pensjon på å fortsette å jobbe samtidig som man tar ut pensjon fra folketrygden. Samtidig tjener man jo mer den tiden man jobber.

\section{Lavere pensjon}

Den økonomiske friheten oppleves nok som ekstra stor for mange av dagens 60-åringer med gunstige pensjonsordninger. Det er imidlertid ikke sikkert at dagens førti- og femtiåringer ansatt i helsesektoren vil føle det samme. Mange vil oppleve at pensjonen er langt lavere enn de hadde forventet og at det man tar ut i pensjon som 62-åring vil spise av fremtidig pensjon.

I helsesektoren er det mange kvinnelige ansatte som har jobbet deltid og som tidvis har vært ute av arbeidslivet i fødsels- og omsorgspermisjon. Arbeidstakere i denne gruppen vil ha lav pensjonsopptjening, og særlig enslige vil kunne føle seg tvunget til å fortsette i jobben av økonomiske grunner selv om man føler seg aldri så sliten.

\section{Nye ordninger}


I en periode prøvde en rekke kommuner ut ordninger der arbeidstakere kunne jobbe 90 prosent med full lønn eller 80 prosent med 90 prosent lønn. Disse ordningene ble naturlig nok satt pris på av arbeidstakerne, men resulterte ikke nødvendigvis i høyere avgangsalder. Dessuten var ordningene kostbare. De fleste kommuner har derfor gått bort fra dette. I staten har det blitt innført en ekstra friuke for arbeidstakere over 60 år, og enkelte arbeidsgivere tilbyr ytterligere noen fridager for medarbeidere over 62 år.

\section{«Yrkesaktiviteten for personer over 50 år har økt de senere årene.»}

En studie av Hermansen (4) viser at disse ordningene har en viss effekt på en forlenget yrkeskarriere. Samlet sett ser det ut til at muligheten for ekstra fridager kombinert med de nye pensjonsordningene har hatt en viss effekt på avgangsalderen fra arbeidslivet. Yrkesaktiviteten for personer over 50 år har økt de senere årene. Økningen har vært særlig stor i aldersgruppen 63-66 år (5). Gjennomsnittlig avgangsalder for Norge var 63,6. For helse- og sosialsektoren var tallet cirka 64 år (6).

\section{Hva mener arbeidstakerne?}

Når arbeidstakere i helsesektoren selv skal angi hvilke tiltak som kunne bidra til å forlenge arbeidskarrieren, nevner mange redusert arbeidstid, lengre ferie og/eller mer fleksibel arbeidstid. Dette er tiltak som kan bidra til at man mestrer et belastende arbeid lenger ved at man får økt mulighet til å ta seg inn mellom arbeidsøktene. Mange ønsker også at arbeidet var mindre fysisk og psykisk belastende. I tillegg ønsker mange organisatoriske endringer som for eksempel gjør det mulig, i større grad, å bestemme arbeidstempoet og arbeidstiden selv. Også bonus og høyere lønn kunne få en del til å vurdere å fortsette i arbeid.

En del mener dessuten at de ville fortsette å jobbe dersom ledelsen i større grad enn i dag viser at den setter pris på deres kompetanse og arbeidsinnsats (7). For de fleste sykepleiere vil arbeidsgiver sjelden eller aldri være i stand til å etterkomme alle disse ønskene grunnet knapphet på både kompetanse, økonomiske ressurser og rigide turnusordninger som ikke er lett å myke opp. Gitt disse begrensningene, blir det særdeles viktig å oppleve at arbeidet er meningsfullt og preget av mestring og arbeidsglede.

\section{Arbeidsglede i alle aldre}

I tillegg til preventive helsetiltak og økonomiske incentiver, vil et av de viktigste seniortiltakene være å satse på arbeidsglede. Arbeidsglede oppnås når det er en rimelig balanse mellom de fysiske og mentale krav som stilles til jobben og de ressurser som arbeidsgiver og medarbeider legger i potten. I tillegg til kompetanse kan medarbeideren stille med tro på egen mestring, stå-på-evne, selvrespekt og forhåpentligvis optimisme.

\section{«Et godt arbeidsmiljø er preget av at det skal stilles krav til medarbeideren.»}

Arbeidsgiveren kan gi arbeidstakeren verktøy, kompetanse, rom og autonomi til å løse arbeidsoppgavene, sosial støtte, tilbakemeldinger og et godt arbeidsmiljø. Når disse betingelsene er på plass, utløses gjerne et jobbengasjement som igjen resulterer i økt produktivitet og brukertilfredshet, og det skapes en god sirkel som virker inn på arbeidsgleden (8). 
Det er selvfølgelig viktig å opprettholde arbeidsgleden i alle aldersgrupper. Et godt arbeidsmiljø er preget av at det skal stilles krav til medarbeideren. Spørsmålet må da være «hvilke krav»? Krav kan man forhandle om, og det er ledelsens og HRs oppgave å legge til rette for fornuftige forhandlinger som er praktisk gjennomførbare, for eksempel om arbeidsoppgaver, arbeidsbelastninger og arbeidstid, herunder turnus.

\section{En lederutfordring}

Selv om det som regel er en individuell beslutning om man skal fortsette å jobbe eller ikke, er det ledelsens ansvar å sørge for en personalpolitikk som gjør det mulig og ønskelig for den enkelte å stå i jobben. Mange ledere ser at det er et samfunnsansvar å bidra til at medarbeiderne står lenger i arbeid, og i IA-virksomheter (virksomheter som har inngått avtale om inkluderende arbeidsliv) har ledelsen ofte uttrykt en intensjon om å ha en seniorpolitikk. Det er imidlertid ikke nok med en intensjon.

Ledere må i praksis ta aktivt grep for å bidra til at medarbeiderne skal klare å stå lenge i jobbene sine. Noen ledere har et spesielt blikk for alder, og det er deres erfaringer og praksis vi skal se nærmere på i det følgende. En nærmere beskrivelse finnes i Terjesen og Salomon (9) og Terjesen og medarbeidere (10).

\section{Transformasjonsledelse}

I studier av ledere har det blitt populært å sette merkelapper på lederne ut fra hvilke lederegenskaper de fremviser i ulike tester. En ledelsesform som baserer seg på bruk av testing er «transformasjonsledelse».

Transformasjonsledere kjennetegnes ved at de er rollemodeller som går foran med besluttsomhet, utholdenhet og et veljustert moralsk kompass. Disse lederne motiverer og inspirerer sine medarbeidere ved å gi dem meningsfulle og utfordrende arbeidsoppgaver. De stimulerer også til kreativitet og inkluderer medarbeiderne til å sette ord på problemer i virksomheten, til å stille spørsmål ved gamle sannheter og til å løse oppgaver på egen hånd. De tar også individuelle hensyn ved å «se» den enkelte medarbeider og anerkjenne medarbeiderens behov $(9,11,12)$.

\section{Blikk for alder}

I våre studier fra pleie- og omsorgssektoren (10) ble det foretatt 53 strukturerte intervjuer med 44 ledere og 9 tillitsvalgte. 40 av lederne fylte også ut spørreskjemaet «Multifactor Leadership Questionnaire» (MLQ) som kartla deres ledelsesprofil. Sju av dem (fem kvinner og to menn) fikk en profil som karakteriserte dem som transformasjonsledere. Den yngste var 37 år og den eldste 61 år.

Felles for alle disse lederne var at de hadde en betydelig bevissthet om den eldste arbeidskraften i virksomheten, og aktive strategier for å få til en vellykket samhandling og arbeidsdeling på tvers av alder, livsfaser, preferanser og arbeidsevne. De hadde med andre ord blikk for alder. Det viste seg også at hos disse lederne var det et lavere sykefravær enn hos de andre lederne i undersøkelsen.

\section{Den vanskelige turnusen}


Å legge turnusplaner er ofte en vanskelig kabal hvor det slett ikke er lett å ta hensyn til alle. Enkelte ledere er svært rigide i praktisering av turnusordninger, mens andre viser større fleksibilitet. På enkelte arbeidsplasser er arbeidstakerne ganske flinke til å bytte turnus seg imellom ved behov uten å involvere ledelsen. Det er imidlertid også mulig å tenke aldersstrategisk i oppsett av turnus. Et eksempel er en 50 år gammel kvinnelig leder i et sykehjem. Hun uttalte følgende:

«Jeg har også hatt egne helgeturnuser for ungdom ... For jeg vet at ungdom går på byen i helgen, og da er det mye bedre at de jobber dagtid på lørdag og kvelden på søndag ... Det synes jeg er helt greit, fordi ellers så får vi den der fyllesyken på søndag morgen, og den er ikke all right ... Men, tilrettelagte turnuser kan også brukes for seniorer, for det har mye å si om de jobber kveld eller dag, altså. Dette har iallfall fungert hos meg. Det er mye som kan gjøres».

\section{Strategisk tenkning}

Her ser vi et eksempel på strategisk tenkning som tar hensyn til de sammensatte behovene hos de ansatte. Det er et eksempel på en proaktiv handling som er mer enn en respons på tilfeldige ønsker og behov som måtte dukke opp hos de ansatte, og dermed et viktig seniorpolitisk tiltak der det er mulig. Det er interessant å merke seg årsaken til at lederen skapte denne turnusen.

Hun så at de unges tidvis noe mer «umiddelbare» livsførsel kunne medføre fravær og dermed konflikt og avstand mellom de yngre og de eldre på arbeidsplassen. Ledernes formål med å lage livsfasetilpassete turnuser var derfor først og fremst for å unngå splittelse og konflikt innad på avdelingen. Hun fikk til en tilpasning etter alder og preferanser, og virksomheten kunne også vise til godt samhold og et svært lavt sykefravær (2 prosent).

\section{Også eldre ønsker å bli sett}

En viktig arbeidsmiljøfaktor er behovet for å bli sett og verdsatt (13). Det gjelder også eldre arbeidstakere. De fleste lederne i studien vi refererer til, skjønte dette og la vekt på å møte sine medarbeidere ansikt til ansikt ganske ofte. Noen deltok aktivt i pleien selv om det ikke var en del av stillingsbeskrivelsen, og de hadde en «åpen dør-praksis» som gjorde det lett for medarbeiderne å kontakte dem. En 45 år gammel mannlig leder i hjemmetjenesten uttrykte det slik:

«Spør noen om du har et minutt, har jeg det, selv om jeg ikke har det»

Hyppig kontakt med medarbeiderne ansikt til ansikt skaper nærhet og gjør det mulig for lederne å bli kjent med hver enkelt medarbeider. Det gjør det mulig å identifisere forskjeller og likheter mellom unge og gamle, både på individ- og gruppenivå. Gjennom denne tette kontakten får lederen kjennskap til mangfoldet på arbeidsplassen og er derved bedre rustet til å skjønne den enkelte medarbeiders behov og behovene til ulike aldersgrupper der det er noen forskjell.

Det sier seg selv at toppledere på store arbeidsplasser ikke har mulighet for en slik nærkontakt. Derfor er det viktig at mellomledere og HR-ansatte sørger for å ivareta dette kontaktbehovet.

\section{Ulike forventninger hos unge og eldre}


En del av våre observasjoner er hentet fra sykehjem. Det er mulig at medarbeidernes forventninger til hvordan det skal være på arbeidsplassen er mer lik for de ulike aldersgruppene på sykehus. På sykehjemmet så det ut til at de eldre medarbeiderne ville ha orden i sysakene. Dette sa en kvinnelig leder på 34 år på et sykehjem:

«De eldre, de er vant til å ha avdelingsleder som ordner opp. Det skal være blyanter på pulten, det skal være nok ... Altså nesten på dopapirnivå ... at avdelingslederen skal være, om ikke med i stell, så skal avdelingslederen være mye på avdelingen, sørge for at det er nok av alt i alle skap, altså den typen arbeidsoppgaver. De yngre, de vet at dette her det fikser de selv, altså det her, det ordner de. De tar gjerne ansvar for det ...»

De yngre vil heller ha en sjelesørger og en administrativ leder. Mens de eldre er ute etter orden, ser det ut til at de yngre i større grad er ute etter en som kan veilede og støtte når livet går i bølger.

De yngre lever som regel et mer turbulent liv, de kan ha mindre kontroll over økonomien, de sover dårlig om natten som spedbarnsforeldre og har logistikkutfordringer som småbarnsforeldre. En leder må forstå og prøve å ta hensyn til de ulike behovene i de ulike livsfasene. Det vil komme alle til gode og vil være et godt seniorpolitisk tiltak.

\section{Produksjonslogikk vs. omsorgslogikk}

I pleie- og omsorgssektoren er det mange som rives mellom det man kan kalle produksjonslogikk og omsorgslogikk i sitt daglige virke.

Produksjonslogikken preges av strenge tidskrav, begrensete økonomiske ressurser og rigide styringssystemer. Omsorgslogikken preges av å ha pasienten i fokus og ta seg nok tid til emosjonell omsorg i tillegg til å foreta målinger, medisinering og så videre.

En god leder har forståelse for krysspresset mellom de to logikkene.

Sykepleiens omsorgslogikk er individuell, konkret og situasjonsavhengig. Den er rettet mot helse, helhet, langvarig hjelp til selvhjelp og bygger i stor grad på «taus kunnskap» og en holistisk tilnærming (14).

I vår undersøkelse kom det fram at eldre pleiere ofte ønsket å yte det lille ekstra ovenfor pasientene selv om det medførte ekstra kroppslige belastninger. Dette gjaldt også ofte i tilfeller hvor alle hjelpemidler ikke var på plass

Mange valgte også å bruke mer tid enn normert hos en pasient, selv om det førte til ekstra tidspress for pleieren. Samtidig var det nettopp det å yte noe ekstra overfor pasientene som ga indre motivasjon. Lederens oppgave ble i disse tilfellene å avveie hensynet til effektiv drift og pleierens helse på den ene siden, mot pleierens ønske om ekstra omsorgsfull pasientbehandling på den andre.

I slike tilfeller støttet gjerne transformasjonslederen pleieren så langt som mulig, selv om pleieren bevisst brøt med vedtatte rutiner.

\section{«Eldre kan være noe mindre endringsvillige enn øvrige medarbeidere.»}


Videre viste vår undersøkelse at krysspresset mellom produksjonslogikk og omsorgslogikk kan oppleves ekstra sterk hos eldre medarbeidere, og særlig i forbindelse med omstillinger. Eldre kan være noe mindre endringsvillige enn øvrige medarbeidere, for eksempel i forbindelse med samhandlingsreformen.

Dersom de heller ikke har oppjustert kompetanse om nye krav, går det ut over motivasjonen deres til å fortsette å jobbe. Med andre ord kan ledere gjøre sine medarbeidere en bjørnetjeneste hvis de velger å pensjonere kravene til dem før de rent faktisk går av med pensjon.

\section{Læring som et risikoprosjekt}

En grunnbetingelse for at eldre arbeidstakere skal fortsette å jobbe er at de har oppdatert kompetanse. Samtidig må man se i øynene at mange eldre arbeidstakere opplever det å ta del i opplæringstiltak som et risikoprosjekt. Barrieren for læring hos enkelte eldre arbeidstakere er stor og læringskurven kan i en del sammenhenger være langt slakkere enn for yngre.

Ved å gå inn i en læringsprosess sammen med kollegene vil man kunne eksponere egne svakheter overfor kolleger og ledere på en ubehagelig måte. I tillegg vil man kunne eksponere sine svakheter overfor seg selv, noe de fleste synes er lite lystig. Vi har derfor en tendens til å etablere det Agerys og Schõn (15) beskriver som defensive rutiner.

Om læring kan vi etablere alle mulige teorier for hvorfor det ikke er nødvendig å ta et videreutdanningskurs. Noen kan for eksempel argumentere med at det er fornuftig arbeidsdeling at noen av kollegene lærer seg spesialiserte behandlingsteknikker mens de selv ønsker å rendyrke de teknikkene de er gode på fra før. Det kan være fornuftig i noen tilfeller, men samtidig en defensiv rutine av frykt for omkostningene ved å lære det nye programmet.

\section{Trygge læringsarenaer}

En god HR-strategi må derfor være å etablere trygge læringsarenaer der settingen for læringen virker vennlig i den forstand at den eldre arbeidstakerens egne begrensninger blir mindre eksponert for de andre, og hvor progresjonstakten også kan være noe løsrevet fra de andres tempo.

Ulike sertifiseringsordninger kan være en god hjelp til å «tvinge» eldre arbeidstakere til kontinuerlig læring. I så ulike bransjer som rutebilnæringen, såkalte kunnskapsbedrifter og utdannings- og helsesektoren har vi observert eksempler på obligatoriske opplæringsopplegg og sertifiseringer.

For enkelte kan opplæringen føles belastende så lenge den foregår, men resultatet kan være oppløftende. I alle de nevnte sektorene har vi observert arbeidstakere rundt 70 år som fortsatt blomstrer og har en fremtid på jobben fordi de har fått anledning til å delta i sertifiseringsopplegg gjennom hele karrieren.

\section{Motivasjonssamtalen}


Medarbeidersamtaler/seniorsamtaler kan være en start for å få eldre medarbeidere til å stå lenger i jobben. Det ser imidlertid ut til at altfor mange medarbeidersamtaler egentlig er ganske innholdsløse og ritualistiske. Dersom man virkelig ønsker å beholde en medarbeider er det som nevnt viktig at medarbeideren blir sett, at lederen har blikk for alder, er villig til å ta individuelle hensyn der det er mulig og signaliserer at virksomheten setter pris på medarbeideren og ønsker at vedkommende skal fortsette.

Noen arbeidstakere har bestemt seg for å slutte ved første mulighet for førtidspensjon. Da ser det ikke ut til å nytte hva enn lederen sier eller lokker med. En del velger for eksempel å slutte når ektefellen går av med pensjon. Vi skal ha respekt for folks valg, og det er liten hensikt å bruke tid og krefter på å prøve å overtale en person som har bestemt seg. Da er det viktigere å bruke kreftene der det er mulig «å få napp».

Altfor mange arbeidsgivere har mistet gode seniorer fordi de ikke la ned nok direkte innsats da de hadde muligheten. Et fellestrekk ved ledere som hadde lyktes i å få enkelte eldre medarbeidere til å stå lenger i arbeidet, var at de insisterte på at arbeidsgiveren hadde behov for medarbeideren videre fremover. De var lydhøre overfor eventuelle behov disse medarbeiderne hadde, og de var villige til å strekke seg langt for å ivareta disse medarbeidernes behov.

\section{«Det er all grunn til å rette oppmerksomheten mot seniorpolitikk gjennom ledelse.»}

Forskning fra flere bransjer tyder på at flere ledere legger vekt på å ta opp spørsmål om senkarrieren med medarbeidere, ikke som et eksplisitt seniorpolitisk tiltak, men som del av innarbeidete rutiner. I enkelte kunnskapsbedrifter finner slike samtaler sted flere ganger i løpet av året. Det gir mulighet for en relativt hyppig og tett kontakt mellom medarbeider og leder i en ellers travel hverdag.

En mulighet er å kombinere individuelle seniorsamtaler med gruppesamtaler/dialogverksted mellom eldre arbeidstakere og ledelsen og HR-folk slik blant annet Hilsen og Midtsundstad (16) anbefaler. Det vil gi mulighet til å løse felles utfordringer i en utviklingsprosess og ikke bare som individuelle tiltak. Ved å ha blikk for alder, å vise fleksibilitet selv i rigide systemer, og ved å se medarbeiderne, kan ledere ha sterk påvirkningskraft på om seniorene ønsker å stå lenger i arbeid eller ikke. Det gjelder ledelse på alle nivåer. Det er derfor all grunn til å rette oppmerksomheten mot seniorpolitikk gjennom ledelse innenfor helsesektoren.

\section{Referanser}

1. Roksvaag K, Texmon I. Arbeidsmarkedet for helse- og sosialpersonell fram mot år 2035 Dokumentasjon av beregninger med HELSEMOD Oslo Kongsvinger: Statistisk sentralbyrå; 2012. 14.

2. Skjøstad O. Økt behov for sykepleiere i årene som kommer Statistisk sentralbyrå. 2017 Tilgjengelig fra: https://www.ssb.no/helse/artikler-ogpublikasjoner/okt-behov-for-sykepleiere-i-arene-som-kommer (nedlastet 10.01.2018). 
3. Lie JAS, Arneberg, Goffeng LO, Gravseth HM, Lie A, Ljoså, CH, Matre

D. Arbeidstid og helse. Oppdatering av en systematisk litteraturstudie.

STAMI-rapport nr. 1/2014. Tilgjengelig fra: https://stami.no/wp-

content/uploads/2015/03/STAMI-rapport-nr-1-2014.pdf (nedlastet

10.01.2018).

4. Hermansen Å. Retaining Older Workers. (Doktoravhandling.) Oslo:

Fakultet for samfunnsvitenskap, Høgskolen i Oslo og Akershus; 2016.

5. Nordby P, Næsheim H. Yrkesaktivitet blant eldre før og etter

pensjonsreformen. 2016. Oslo/Kongsvinger: Statistisk sentralbyrå; 2017.

Rapporter 2017/05. Tilgjengelig fra: https://www.ssb.no/arbeid-og-

lonn/artikler-og-publikasjoner/yrkesaktivitet-blant-eldre-for-og-etter-

pensjonsreformen.2016 (nedlastet 10.01.18).

6. Haga O, Lien OC. Utviklinga i pensjonering og sysselsetjing blant seniorer. Arbeid og velferd 2017. Tilgjengelig fra:

https://www.nav.no/no/NAV+og+samfunn/Kunnskap/Analyser+fra+NAV/Arbeid+og+velferd/Arbeid+og+velferd/utviklingai-pensjonering-og-sysselsetjing-blant-seniorar (nedlastet 10.01.18).

7. Midtsundstad T, Bogen H. Flere hender i pleie- og omsorg. Hvordan kan seniorpolitikken bidra? Oslo: Fafo-rapport; 2011.08.

8. Bakker AB og Demerouti E (2007) The Job-Demand Resources Model:

State of the art. Managerial Psychology, 22(3) 309-328.

9. Terjesen Chr Aa, Salomon RH. Langsiktig ledelse. Om bærekraftig aldring i arbeidslivet. Oslo: Cappelen Damm akademisk; 2015.

10. Terjesen CAA, Lau B, Salomon RH. «Er du her så regner jeg med deg!» En studie av god ledelse innen pleie og omsorg: Hvordan kan utøvelse av ledelse bidra til å forlenge yrkeskarrieren for seniorer i en sektor preget av tidligpensjonering og uførhet? AFI Rapport 19/2012. Oslo: AFI; 2012.

11. Bass BM, Riggio RE. Transformational Leadership. London: Lawrence Erlbaum Associates Publishers; 2006.

12. Glasø L, Thompson G. Transformasjonsledelse. Oslo: Gyldendal Akademisk; 2013.

13. Sørhaug T. Om ledelse. Makt og tillit i moderne organisering. Oslo: Universitetsforlaget;1996.

14. Blomgren M. Resultatansvarets betydning for sjukskøterskornas professionalisering. I Berntsen, Zeuthen, Borum, Erlingsdottir og SahlinAndersson: Når styringsambitioner møder praksis. Denmark:

Handelshøgskolens Forlag; 2001.

15. Argyris C, Schön D. Organizational learning: A theory of action perspective, Reading, Mass: Addison Wesley; 1978.

16. Hilsen A, I \& Midtsundstad, T. Seniorpolitikk - behov for nytt kart og kompass. Søkelys på arbeidslivet. 1-2 2014. 